\title{
ETHICS AND THE PRACTICE OF HIV MEDICINE AT THE BEGINNING AND THE END OF LIFE
}

\author{
D C Spencer, $M B C h B$, MMed (Int Med), DTME H \\ fohannesburg, South Africa
}

\section{INTRODUCTION}

I am often asked whether I think that the HIV epidemic has any intrinsic meaning. The question may be better put by asking what I have learnt from this epidemic, and in what ways I, and the society I live in, have changed in order to survive and grow through this epidemic. The area of ethics - the moral high ground of medical practice - is a place where such questions begin to be answered.

'What is joy? What is sorrow?' Bonhoeffer asks the question in one of his final poems' before his execution by the Nazis in 1945.

\section{Time alone can decide between them, \\ When the immediate poignant happening \\ Lengthens out to continuous wearisome suffering. \\ When the laboured creeping moments of daylight \\ Slowly uncover the fullness of our disaster; \\ Sorrow's unmistakable features.}

Then do most of our kind

Sated, if only by the monotony

Of unrelieved unhappiness,

Turn away from the drama, disillusioned,

Uncompassionate.

\section{0 you mothers and loved ones - then, ah, then \\ Comes the hour, the hour for true devotion. \\ Then your hour comes, you friends and brothers! \\ Loyalty can change the face of sorrow: \\ Softly encircle it with love's most gentle \\ Unearthly radiance.}

\section{THE LANGUAGE OF ETHICS}

When discussing ethical issues it has become commonplace to use several principles as scaffolding upon which the debate can be constructed. ${ }^{2}$ These are the following:

Erimum non nocere - 'First do no harm'. The concept of not harming our patients is enshrined in the Hippocratic Oath, a document from antiquity that reminds all who would follow the path of Aesculapius that the medical profession's calling is where possible, that of healer and preserver of life.

- Autonomy. This concept enshrines the right to selfgovernment, personal freedom, the freedom to express my own will. As with all freedoms this freedom is best understood within the context of community or society. Here personal liberty is protected and given agreedupon boundaries.

- Beneficence. The name given to the work of 'doing good', 'being generous', 'being actively kind'. Beneficence carries with it pictures of Mother Teresa among the down-and-outs of Calcutta or Florence Nightingale on the battlefields of the Crimea. Something done that is so obviously good that none would refute the action or its underlying motive.

Non-maleficence. No evil, no hurtful intent, no criminal agenda. The term suggests that the motive for an action has no inherent evil associated with it. It is the sort of term that should make us question our motives, do constructive soul searching, ask ourselves why we took such a course of action. This is the sort of term that those of us who practised our medicine during the apartheid years need to examine: did I benefit from the system?? 'Mr Clinton did you have sex with Miss Lewinsky?'

- Justice. This may be defined as the 'moral obligation to act on a fair basis in the adjudication between competing claims.'. More simply put, it's the idea of 'just conduct', 'fairness', 'doing the right thing'. It's an idea that is rooted in our religious heritage and anticipates that we live in a 'fair and just' universe. The honest man examines even his religious foundations: 'For He [God] is not a man, as I am, that I may answer Him. And that we could go to court together. Nor is there any mediator between us who may lay his hand on us both. ${ }^{15}$ So says the patriarch Job.

When considering the context of HIV/AIDS a further term needs to be introduced:

Futility. This Latin word conveys the sense of leakiness 
- the basin that won't hold water, useless, ineffectual, pointless. Medical actions that are futile are deemed to be unlikely to produce any significant benefit for the patient. $^{6}$

Ethics has a narrow and a broad focus - the individual, his/her needs and those of their immediate family and dependents. Ethics also incorporates society and particularly in the HIV epidemic, demands that the wider issues that concern public health be addressed. Unfortunately this requires that a few more concepts be brought to the reader's attention.

- The utilitarian approach to public health. Two centuries ago the British philosopher Jeremy Bentham coined the phrase 'the greatest happiness of the greatest number?' Utilitarianism can be highly selective and subjective. The provision of antiretroviral drugs for the prevention of mother-to-child transmission (MTCT) has been seen by many as too expensive, too difficult to implement, likely to increase the number of AIDS orphans: in short, detrimental to those South Africans who are uninfected and to a government that will have to fund the necessary care. "In a lifeboat, is it acceptable to kill a few castaways and eat them so that the rest of the group can survive? And if so, should we choose the least happy, the least popular, or the most nutritious to sacrifice?' Who do we sacrifice? ${ }^{8}$ Ethics has to do with moral choices and dilemmas.

- The libertarian approach to public health. All human beings have rights. These rights are acknowledged in the United Nations Charter and in constitutions such as that which governs conduct in South Africa. Liberalism in this context views individual rights as paramount. Hence human beings should be treated with respect, as ends in themselves, not as the means to another individual's end or only where such rights are in agreement with those of 'the greatest number'. But asserting a right to health for everyone, begs a number of questions. Can all HIV-infected South Africans be provided with antiretroviral drugs? This is likely to be financially and logistically impossible. The Essential Drug List of 1998 makes it clear that access to many drugs, including the antiretrovirals, is beyond the scope of the current government. It ought to be remembered, however, that those who wrote the Essential Drug List are themselves exempt from following its dictates. These authors generally access their health care outside the public system. What rights do the HIV-infected and their children possess in this country? Our courts are busy defining answers to these questions.

- The communitarian approach to public health. What is 'right' for society? Individual rights versus the rights of community or lobby groups within society. How do we cater for all? In their article, Roberts and Reich recall: 'History has many examples of people who sought to impose their communitarian vision by force - from the Crusades to the Khymer Rouge to the Taliban. Moving from coercion to coexistence, tolerance, and mutual learning requires a degree of openness that many universal communitarians find inconsistent with their own vision. This approach focuses on creating a good society, and producing the right individuals for that society. Within the context of the HIV debate and MTCT in particular, the South African government has taken decisions based upon its mandate as the governing body of society, and sought to impose its will on its subjects. This has been despite the negative press it has received locally and abroad. President Mbeki's dissident opinions were upheld conscientiously by his ministers of health - only recently does this viewpoint seem to have altered. Ethical positions require that those holding them give adequate reasons for their viewpoint. Government has not given any reason for its changed stance on MTCT other than that it is obeying the court ruling against it. Roll-out and implementation will indicate whether central government is truly committed to changing its policies. Good governance can be judged by openness, transparency and delivery.

The 'ethics of care' approach to public health. This approach asks 'How would you want to treat everyone in society if you imagined yourself as everyone's parent? ${ }^{\prime 10}$ Family life, human relationships and caring in general need to be taken seriously. If this were the case, governments would develop more caring and nurturing policies towards the health of their people. In such a society, a 'family-orientated' approach would lead to less stigmatisation, more tolerance of failure, greater space to ventilate hurts and talk through personal issues. Within the context of South Africa, it needs to be said that our failure to nurture our families, and to demonstrate to our children that we love them, is central to the HIV problem." South African society is still fragmented: single parents, children growing up on their own, poverty and wealth existing side by side, racism and xenophobia and uncontrolled criminality, sexual violence and the common abuse of women and children, a constitution that honours personal worth yet cannot protect its citizens, a government that has shown itself reluctant to prevent the HIV infection of thirty to forty thousand newborns each year. Family values. These would need to be re-defined to have any meaning to the average South African: where would you send people to re-learn these values? When we are having trouble with the equation, are we likely to get to the answer? 


\section{THE HIV EPIDEMIC IN SOUTH AFRICA}

\section{THE EPIDEMIOLOGY}

Worldwide, sub-Saharan Africa has borne the brunt of the epidemic. South Africa has more than 5 million HIVinfected citizens and the epidemic has yet to plateau, possibly somewhere between 2005 and 2010 . Seroprevalence rates among young mothers at antenata clinics in Gauteng and KwaZulu-Natal are between 25\% and $35 \%$. More than $20 \%$ of the workforce of several large South African companies is infected. HIV-positive patients occupy $50-60 \%$ of bed-space in the public hospitals of Gauteng. The impact upon society as a whole is beginning to be felt: funerals, sick leave and absenteeism, AIDS orphans and abandoned children, health care systems that fail to deliver adequate care to the sick. Life expectancy has dropped. The region's economy is expected to decline in the long term. Twenty-one years into the epidemic new infection rates remain high. All South Africans are affected: young and old, rich and poor, black and white, men and women, the educated and the illiterate. ${ }^{12,13}$

\section{BASIC SCIENCE}

The acquired immune deficiency syndrome (AIDS) is caused by a virus. This virus is called the human immunodeficiency virus (HIV). Its means of spread was defined in the early 1980s: sexual, blood-borne and mother-to-child transmission. The infection can be prevented. While a cure remains elusive, for some the last decade has brought effective control of the infection. Survival beyond $15-20$ years is anticipated with current therapies. Untreated however, $90 \%$ of Americans and Europeans succumb to the virus within $10-12$ years. ${ }^{14}$ Overall survival may be shorter in Africa. Drug therapy is not without its shortcomings. Medication is expensive and even generic substitutes are costly to the very poor. Drugs have side-effects and toxicities, some of which are life-threatening. The antiretroviral drugs must be taken reliably to ensure continued efficacy:drug-resistant virus accounts for approximately $10 \%$ of all newly acquired infections in the West.

\section{HIV AND ITS ROLE IN PEOPLE'S LIVES}

When I counsel I'm in the arena of stigma, betrayal, grief and loss, guilt, anger, fear and shame, and countless other emotions, beliefs, disappointments. I seldom look at joy or even tranquillity, except perhaps briefly when the viral load has become undetectable or the $\mathrm{CD} 4$ cell count has risen unexpectedly. Sometimes I stand at the bedside just looking and wishing I wasn't there: looking into the face of hopelessness and a sadness that is beyond human touch.

It's important to let the people whose lives are being affected by this epidemic speak for themselves. Part of the
'Doctor, your blood keeps you alive. My blood's killing me.'

- 'I know I'm positive but I tell myself no. Now I can go to restaurants and mix with other people. If they knew they wouldn't want to sit with me. They wouldn't want to have anything to do with me. I can be a normal person now.

- 'My life has stopped. I don't talk about this thing to anyone. I don't make love to my wife any longer. We live separate lives.'

- I waited in the bedroom like a good and dutiful wife. And he just dished up this thing called AIDS and brought it to me on a silver platter'.

- 'I sang this song about HIV and AIDS to my family, warning them of it. And now I have it myself!'

healing is about learning to love oneself and those whose lives intertwine with one's own.

\section{DEALING WITH ETHICAL ISSUES ${ }^{15-1}$}

\section{ETHICAL ISSUES AT THE BEGINNING OF LIFE}

The following are some of the questions:

- HIV testing of pregnant women. Should all pregnant mothers be tested for HIV? Is anonymous testing for statistical purposes still acceptable?

- Abortion. What is the role of termination of pregnancy in the HIV-infected?

- Prevention of MTCT. Should we attempt to prevent HIV transmission to the unborn and the newborn? Are the antiretrovirals harmful to pregnant mothers and their babies? Will widespread MTCT result in drugresistant infection in mothers, their babies, their partners?

- Breast-feeding. Is it safe? How can it be avoided without arousing the suspicion of HIV infection in the mother?

Parents. Should the father of the unborn child be informed of his partner's HIV status? Is it wise to plan for more pregnancies?

- Contraception. Is condom use optional?

- Children. Who will care for the orphans and the sick child? Will the prevention of breast-feeding harm the future of the growing child?

\section{ETHICAL ISSUES AT THE END OF LIFE}

The following are some of the questions:

- Defining the 'end of life'. Who decides when enough is enough?

Defining what 'limited resources' means. Where resources are limited, how are they to be distributed (fairly) to those who are HIV-infected? 
Defining the role of antiretrovirals in 'end-of-life' care. When is 'salvage therapy' a pointless exercise?

- Euthanasia and palliative care. Who will give the lethal injection? Is there capacity in South Africa to offer acceptable palliative care?

- Home-based care of the terminally ill patient. What responsibilities rest with the state or local government or private individuals with regard to the management of the sick and dying in their or someone else's home? NB: Many final illnesses in the patient with AIDS are infectious in nature and several may be contagious: tuberculosis, salmonella, cryptosporidiosis, Pneumocystis carinii, etc. Diarrhoeal illnesses, open wounds and sores, blood spills in the home may permit the spread of infectious viruses (hepatitis B and C, HHV8, HIV) and bacteria (staphylococci, coliform bacteria, etc.) to the caregiver. Should visitors to the home and members of the family be made aware of the risks?

Death. What should be told to the immediate next of kin and how is confidentiality maintained? What should be stated on the death certificate? Can the diagnosis of HIV be excluded from the insurance claim report?

Comment: Real-life problems relating to HIV and people must take into account the discussion under Section 1 above: primum non nocere, autonomy, beneficence, nonmaleficence, justice and futility. In addition, a particular circumstance must be viewed within the broader framework of what is best for the individual, what is best for the community, what are the appropriate rights of the individual and society and what is the best way forward. The background to each question will have some scientific or 'evidenced-based' truth - this must be incorporated into the appropriate answer.

\section{CASE REPORTS}

\section{Neville and Dorcas}

Sometime in 1997 Neville found himself in bed with his domestic worker. Neville is a bachelor in his early thirties and a medical doctor. Dorcas, his domestic worker, had several small glands in her neck. He had her tested. She was HIV-positive. I was called to give advice about postexposure prophylaxis - Neville had not been using condoms - and to counsel Dorcas. Neville was HIVnegative. Dorcas was given an appointment to see me at the HIV Clinic at Johannesburg Hospital.

About 6 months later Neville phoned me: Dorcas was 19 weeks pregnant. Could I arrange an abortion for her? Neville was sure he was the father. He was uncertain what to do: Dorcas wanted the baby but Neville's own family advised against continuing the pregnancy. Neville hadn't been using condoms regularly. The pregnancy hadn't been planned. He wasn't sure whether he wanted the relationship between himself and Dorcas to continue. I was busy with medical students and didn't have time to talk. 'Neville, do what your heart tells you to do.' I hung up the phone and went back to the students.

They decided against an abortion. I gave advice about the prevention of MTCT and the couple decided to begin a more formal relationship. Their daughter was born some months later and is now 4 years old. The child has remained HIV-negative. Dorcas is well and on antiretroviral treatment and attends clinic regularly.

\section{Shorty}

I was called about 8.30 in the morning. Office workers in the building next door to the Kenridge Hospital where I worked had called security. A young man was bathing nude in the fountain in the entrance hall to their building. They were particularly worried about the expensive fish in the pool...

Shorty had been on all the available antiretrovirals and now had untreatable, resistant virus. When I got to him he told me he had met Jesus at Rhema Church two days before. He had been healed of his AIDS and commissioned with a special task. 'I am the new Shorty, I am not HIV-positive.' He was aggressive and three security guards had to hold him down while we put his clothes on him. He refused to see the psychiatrist and refused to take any sedative medication. 'I am no longer sick, I am a servant of Jesus. I am the new Shorty!" Neither his wife nor his mother could calm him down. He had been assaulting his wife Noni and she was afraid that he would hurt their 8-month-old baby. She and her baby are HIV-negative. But the police would do nothing unless she laid a formal charge of assault and brought him and witnesses to them. The psychiatrist was reluctant to have him committed to an institution as 'he wasn't truly certifiable'... He clearly was demented and had HIV encephalopathy. Shorty went home. Things seemed to settle over the next week. I recycled him with previous antiviral medication in the hope that it would work. Several months later he drove his car into a tree on the way back from Sun City. He and Noni ended up in the ICU. The baby was unhurt. Shorty and Noni recovered. Noni moved out with her baby. Shorty's mother took him back to their home in Botswana where he died of TB six months later. I recently heard from Noni that her in-laws have accused her of bewitching their son and causing his death. She has been unable to access any of her husband's money or their possessions. A court case is pending.

I have changed patients' names and particulars to maintain anonymity. 
The HIV epidemic in Africa has drawn attention to the vulnerability of women and children to infection with the human immunodeficiency virus. Who will own this epidemic? The government? The health care system? The individual? Without individual people taking responsibility for their lives it seems unlikely that the epidemic will be brought under control in the foreseeable future. A cure is still a long way off, and might never be an option. Prevention remains the only safe haven in our present situation. In the introduction I asked what I have learnt from this epidemic and in what ways our society has changed to combat the virus. In an article about AIDS prevention Bayer" states: 'There are no simple answers that address the needs both for trust and candor in intimate relationships and for security in the era of AIDS. Systematic behavioural research is essential ... Nevertheless, these questions make it clear that matters of sexual ethics are not moralistic diversions. They are at the heart of AIDS prevention:

The ethical issues that arise with regard to the care of the HIV-infected are matters that require skill and sensitivity. South African medicine is unlikely to be remembered for the manner in which the HIV epidemic was handled. Goodwin ${ }^{19}$ comments about the care of the elderly in North America. He is saying things that could well be applied to the management and approach towards the HIV infected in South Africa. 'It is almost as if the relief of suffering is too small a job. This sentiment was evident after the death of Mother Teresa. The recurring observation was that she did nothing to change the root causes of poverty; she only relieved the suffering of some of its individual victims. The belief in progress inherent in this opinion is almost touching in its naivete. It allows people to distance themselves from each other, to treat "root causes". People treating root causes seldom get dirty.'

Our society has distanced itself from the AIDS epidemic. Our politicians prefer to treat 'root' causes while turning their backs on the needs of the vulnerable - women and children - of this epidemic. Our poets foresaw our day:

\section{0 weariness of men who turn from God \\ To the grandeur of your mind and the glory of your action... \\ Though you forget the way to the Temple, \\ There is one who remembers the way to your door; Life you may evade, but Death you shall not. You shall not deny the Stranger. ${ }^{20}$}

In the very near future the Stranger will be found visiting almost all the homes in this land, including those who have turned their back on this epidemic.
REFERENCES

Bonhoeffer D. Letters and Papers from Prison. Abridged ed. London: SCM Press, 1981: $118-119$.

2. Beauchamp TL Childress JF. Principles of Biomedical Ethics. 3rd ed. New York: Oxford University Press, 1989.

3. De Gruchy J, Rubenstein $1 S$. Will South African physicians build a culture of human rights? Lancet $2000 ; 355: 838$

4. Marcus E-L Clarfield M, Moses AE. Ethical issues relating to the use of antimicrobial therapy in older adults. Clinical Infectious Diseases 2001; 33: 1697-1705.

5. The Bible (New King James Version). Job 9: 32, 33.

6. Marco CA, Larkin GL, Moskop JC, et al. Determination of 'futility' in emergency medicine. Ann Emerg Med 2000; 35; 604-612

7. Bentham J. The Principles of Morals and Legislation. Oxford: Clarendion Press, 1996.

8. Roberts MJ, Reich MR. Ethical analysis in public heaith. Lancet 2002; 359: 10551059.

9. Burris S, Lazzarini Z, Bebe L Are human rights good for your health? Lancet 2001; 358: 1901.

10. Baier A. Moral Prejudices: An Essay on Ethics. Cambridge: Harvard University Press, 1994: $21-22$.

11. Baver R. AlDS prevention - sexual ethics and responsibility. N Engl J Med 1996; 334: $1540-1542$.

12. Leader Articles. The Mail \& Guardian 2002; 22-27 March

13. Leader Articles. The Sunday Independent 2002; 24 March.

14. Weidle PJ, Holmberg SD, DeCock K Changes in HIV and AIDS epidemiology from new generation antiretroviral therapy. AlDS 1999; 13: suppl A, S61-S68.

15. Peckham C, Newell M-L. Preventing vertical transmission of HIV infection (Editorial). N Engl I Med 2000; 343: 1036-1037.

16. Coutsoudis A, Pillay K, Spooner E, Kuhn L, Coovadia HM, for the South African Vitamin A Study Group. Influence of infant-feeding patterns on early mother-tochild transmission of HIV-1 in Durban, South Africa: a prospective cohort study. Lancet 1999; $354: 471-474$

17. Slome LR, Mitchell TF, Charlebois E, Benevedes JM, Abrams DI. Physician-assisted suicide and patients with human immunodeficiency virus disease. $N$ Engl I Med 1997: 336: 417-421.

18. Oleske $J M$, Czarniecki $L$ Continuum of palliative care: lessons from caring for children infected with HIV-1. Loncet 1999; 354: 1287-1290.

19. Goodwin JS. Geriatrics and the limits of modern medicine. N Engl J Med 1999; 340: 1283-1285.

20. Eliot TS. Choruses from 'The Rock. In: Selected Poems. London; Faber \& Faber, 1954.

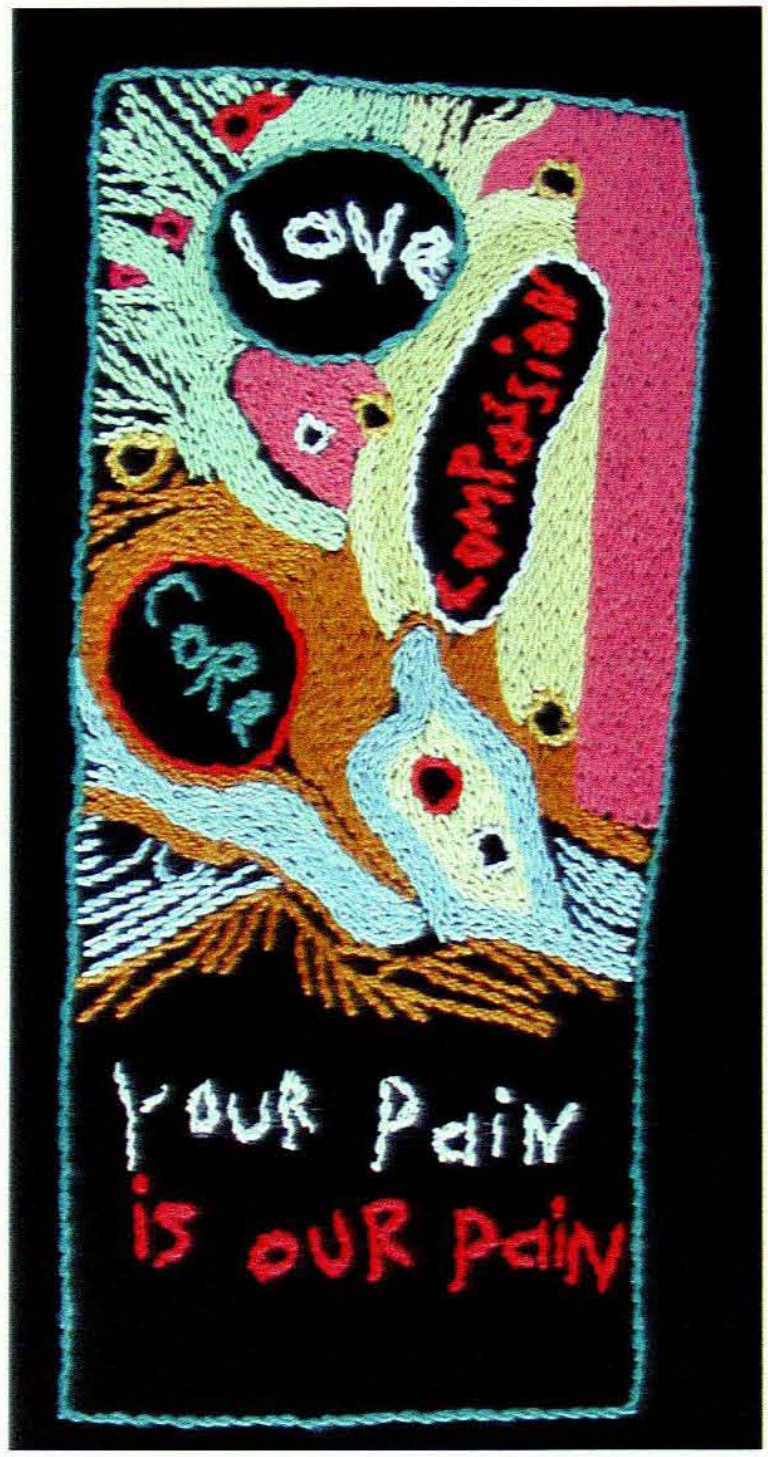

